\title{
UJI PERTUMBUHAN DAN HASIL TANAMAN SAWI DENGAN PEMBERIAN MACAM PUPUK ORGANIK DAN PUPUK NITROGEN
}

\author{
Sri Hidayati ${ }^{1{ }^{*}}$, Nurlina ${ }^{2)}$, Sri Purwanti ${ }^{3)}$ \\ ${ }^{\left.\left.1{ }^{*}, 2\right), 3\right)}$ Fakultas Pertanian, Universitas Merdeka Surabaya \\ email: hidayatisetyo@gmail.com ${ }^{1 *}$, nurlinaraharjo@gmail.com ${ }^{2)}$, purwantialea@gmail.com ${ }^{3)}$
}

\begin{abstract}
ABSTRAK
Sawi khususnya sawi hijau merupakan salah satu jenis sayuran daun, yang banyak dikosumsi oleh masyarakat Indonesia.Tanaman ini sangat berpotensi sebagai penyedia unsur-unsur mineral penting yang dibutuhkan oleh tubuh kita, karena nilai gizinya tinggi. Pertumbuhan tanaman sawi dipengaruhi oleh jenis pupuk yang digunakan, baik itu pupuk organik ataupun pupuk an organik. Tujuan dari penelitian ini adalah untuk menguji pertumbuhan dan hasil tanaman sawi dengan pemberian macam pupuk kandang; untuk menguji pertumbuhan dan hasil tanaman sawi dengan pemberian pupuk Nitrogen; untuk menguji pertumbuhan dan hasil tanaman sawi dengan pemberian kombinasi macam pupuk kandang dan pupuk Nitrogen.Percobaan ini disusun secara faktorial dalam Rancangan Acak Kelompok (RAK), terdiri dari dua faktor yaitu Perlakuan macam pupuk kandang dengan 2 level dan perlakuan pupuk nitrogen dengan 4 level. Masing-masing kombinasi perlakuan diulang tiga kali dan setiap kombinasi perlakuan terdiri 2 (dua) tanaman sample. Faktor I: Macam pupuk kandang $\left(\mathrm{K}_{1}\right.$ :kandang sapi dan $\mathrm{K}_{2}$ : kandang kambing). Faktor II :Pupuk Nitrogen $\left\{\mathrm{N}_{1}: 50 \mathrm{gr} / \mathrm{m}^{2}(4.50\right.$ $\mathrm{gr} / \tan ) ; \mathrm{N}_{2}: 75 \mathrm{gr} / \mathrm{m}^{2}$ ( 6,75 gr/tan ); $\mathrm{N}_{3}: 100 \mathrm{gr} / \mathrm{m}^{2}(9,00 \mathrm{gr} / \tan ) ; \mathrm{N}_{4}: 125 \mathrm{gr} / \mathrm{m}^{2}(11,25$ gr/tan) $\}$. Sehingga terdapat delapan (8) kombinasi perlakuan. Pengamatan yang dilakukan pada penelitian terdiri dari panjang tananmn; jumlah daun dan berat segar tanaman. Hasil penelitian menunjukkan bahwa terdapat interaksi yang nyata pada perlakuan kombinasi macam pupuk kandang dan pupuk Nitrogen terhadap variabel jumlah daun umur 14 HST dan berat basah tanaman. Hasil terbaik ditunjukkan oleh perlakuan kombinasi $\mathrm{K}_{2} \mathrm{~N}_{4}$. Perlakuan macam pupuk kandang berpengaruh sangat nyata terhadap pertumbuhan panjang tanaman umur 14 HST dan berat basah tanaman, sedang pertumbuhan jumlah daun berbeda nyata umur 14 HST.Hasil terbaik ditunjukkan oleh perlakuan pupuk kandang kambing $\left(\mathrm{K}_{2}\right)$.Perlakuan pupuk Nitrogen berpengaruh sangat nyata terhadap semua variabel pengamatan.Hasil terbaik ditunjukkan oleh perlakuan $\mathrm{N}_{4}$.
\end{abstract}

Kata Kunci : Tanaman Sawi; Pupuk Organik; Pupuk Nitrogen

\section{PENDAHULUAN}

Tanaman sawi (Brassica juncea) merupakan salah satu sayuran daun, yang banyak dikonsumsi oleh masyarakat Indonesia. Tanaman ini sangat berpotensi sebagai penyedia unsur-unsur mineral penting yang dibutuhkan oleh tubuh kita, karena nilai gizinya tinggi.Disamping mempunyai nilai gizi tinggi tanaman sawi ini juga berguna dalam upaya mengatasi masalah kekurangan vitamin A(Margiyanto, 2007).

Tanaman sawi di luar negeri lebih dikenal dengan nama Mustard (Brassica Juncea $L$ ). Ada beberapa varietas Mustard asal introduksi antara lain King Mustard, suehliling No. 2 dan Bau sin (Known You Seed Taiwan), serta Swollen-Sten Mustard (Sakala Seed Jepang). Tipe baru dari Mustard ini antara lain varietas Miike Giant, Red Giant, Horned Mustard, 
Mustard Green dan Green Pak Choy. Dibeberapa daerah di Indonesia ada beberapa varietas yang berkembang antara lain, caisin, II/38, caigram IV/3, dan sawi putih (Hariyanto dkk,2001).

Tanaman sawi dikenal sebagai tanaman sayuran daerah iklim sedang (sub-tropis), tetapi saat ini berkembang pesat di daerah panas (tropis). Kondisi iklim yang sangat baik bagi pertumbuhan tanaman sawi adalah kondisi daerah yang menpunyai suhu malam hari $15,6^{\circ} \mathrm{C}$ sampai $21,1^{\circ} \mathrm{C}$ serta penyinaran matahari antara 10-15 jam perhari (Rukmana, 2003). Meskipun demikian, telah banyak varietas yang toleran terhadap suhu panas, sehingga tanaman sawi dapat ditanam atau dikembangkan pada daerah dengan ketinggian mulai $5 \mathrm{~m}-1.200 \mathrm{~m} \mathrm{dpl}$ (Haryanto dkk, 2001).

Pada dasarnya sawi dapat ditanam di berbagai jenis tanah, namun yang baik adalah jenis tanah lempung berpasir, seperti tanah andosol, untuk jenis tanah liat perlu dilakukan pengolahan lahan secara sempurna antara lain dengan pernambahan pasir dan pupuk organik dalam dosis yang tinggi. Jadi syarat tanahideal bagi tanaman sawiadalah subur, gembur, banyak mengandung bahanorganik, tidak menggenang, tata udara dalam tanah berjalan dengan baik dan $\mathrm{pH}$ tanah antara 6-7 (Rukmana, 2003).

Pertumbuhan tanaman sawi dipengaruhi oleh jenis pupukyang digunakan, Petani biasa mengunakan pupuk cair kimia untuk mendapatkan pertumbuhan yang maksimal dan cepat, tetapi efek dari penggunaan pupuk kimia ini adalah pada kesehatan, sehingga diperlukan pupuk yang sesuai yang tidak memiliki efek bagi kesehatan, salah satu alternatif tersebut adalah dengan mengunakan pupuk organik.

Pupuk organik adalah pupuk yang tersusun dari materi makhluk hidup, seperti pelapukan sisa -sisa tanaman, hewan, dan manusia. Pupuk organik dapat berbentuk padat atau cair yang digunakan untuk memperbaiki sifat fisik, kimia, dan biologitanah.Pupuk organik merupakan sumber bahan organik. Dimana Sumber bahan organik dapat berupa kompos, pupuk hijau, pupuk kandang, sisa panen (jerami, brangkasan, tongkol jagung, bagas tebu, dan sabut kelapa), limbah ternak, limbah industri yang menggunakan bahan pertanian, dan limbah kota (sampah).

Pupuk kandang merupakan salah satu contoh pupuk organik yang berasal dari kandang ternak, baik berupa kotoran padat (faeces) yang bercampur sisa makanan maupun air kencing (urine), sehingga kualitas pupuk kandang beragam tergantung pada jenis, umur serta kesehatan ternak, jenis dan kadar serta kandungan haranya (Sangatanan dan Sangatanan, 1989). Hewan yang kotorannya sering digunakan untuk pupuk kandang adalah hewan yang bisa dipelihara oleh masyarakat, seperti kotoran kambing, sapi, domba, dan ayam.Selain berbentuk padat, pupuk kandang juga bisa berupa cair yang berasal dari air kencing (urine) hewan.

Pupuk kandang mengandung unsur hara makro dan mikro.Pupuk kandang padat (makro) banyak mengandung unsur fosfor, nitrogen, dan kalium.Unsur hara mikro yang terkandung dalam pupuk kandang di antaranya kalsium, magnesium, belerang, natrium, besi, tembaga, dan molibdenum.Kandungan nitrogen dalam urine hewan ternak tiga kali lebih besar dibandingkan dengan kandungan nitrogen dalam kotoran padat. Kualitas pupuk kandang sangat tergantung pada jenis ternak, kualitas pakan ternak, dan cara penampungan pupuk kandang.

Pemberian pupuk kandang mampu meningkatkan kesuburan tanah, memperbaiki struktur tanah dengan pemantapan agregat tanah, aerasi, dan daya menahan air, serta kapasitas tukar 
kation(Sari et al., 2020). Struktur tanah yang baik menjadikan perakaran berkembang dengan baik sehingga semakin luas bidang serapan terhadap unsur hara. Kelancaran proses penyerapan unsur hara oleh tanaman terutama difungsi tergantung dari persediaan air tanah yang berhubungan erat dengan kapasitas menahan air oleh tanah (Nurhayati, 2000).

Menurut Sutejo(2002), pupuk organic mempunyai fungsi yang penting dibandingkan dengan pupuk anorganik yaitu dapat menggemburkan lapisan permukaan tanah (topsoil), meningkatkan populasi jasad renik, mempertinggi daya serap dan daya simpan air,yang secara keseluruhan dapat meningkatkan kesuburan tanah. Haryanto (2003) mengatakan bahwa tanaman sawi membutuhkan pupuk kandang sebanyak 10 ton/ha.

Pupuk kandang sapi merupakan pupuk dingin yaitu pupuk yang terbentuk karena proses penguraiannya oleh mikroorganisme berlangsung perlahan sehingga tidak membentuk panas. Pupuk kandang sapi ini dapat menyediakan unsur hara makro dan mikro sehingga dapat mendukung pertumbuhan tanaman karena struktur tanah sebagai media tumbuh tanaman dapat diperbaiki.Mengenali pupuk kandang dari bahan dasarnya sangat sulit. Ini disebabkan oleh bentuk dan warna pupuk kandang tetap sama setelah mengalami proses fermentasi atau pematangan selama sekitar $7-14$ hari. Ciri pupuk kandang yang dapat diaplikasikan ke tanaman atau istilah umumnya sudah matang yaitu terasa dingin saat diraba, remah atau rapuh bila diremas, wujud asli bahan dasar sudah tidak tampak, dan tidak berbau seperti aslinya. Pengaplikasiannya dilapangan dapat dilakukan dengan cara disebar ke permukaan atau dibenamkan $\pm 40 \times 40 \mathrm{~cm}$ dalam tanah disesuaikan dengan kedalam pollybag (Musnamar, 2004).
Pupuk kandang sapi merupakan pupuk padat yang banyak mengandung air dan lendir. Bagi pupuk padat yang keadaannya demikian bila terpengaruh oleh udara maka cepat akan terjadi pengerakan-pengerakan sehingga keadaannya menjadi keras, selanjutnya air tanah dan udara yang akan melapukkan pupuk itu menjadi sukar menembus ke dalamnya. Dalam keadaan demikian peranan jasad renik untuk mengubah bahan-bahan yang terkandung dalam pupuk menjadi zat-zat hara yang tersedia dalam tanah untuk mencukupi keperluan pertumbuhan tanaman mengalami hambatan, perubahan berlangsung sesuai dengan pelakuan masing-masing tanaman sawi.

Pupuk kandang kambing berarti pupuk yang berasal dari kotoran kambing. Kandungan unsur hara pada pupuk kandang kambing yaitu Nitrogen 0,6\%, Phospor 0,3\%, dan Kalium 0,17\%. Tapi, memang kandungan $\mathrm{N}$ dan $\mathrm{P}$ kambing lebih tinggi dibandingkan dengan sapi.

Tekstur dari kotoran kambing adalah khas, karena berbentuk butiranbutiran yang agak sukar dipecah secara fisik sehingga sangat berpengaruh terhadap proses dekomposisi dan proses penyediaan haranya. Nilai rasio $\mathrm{C} / \mathrm{N}$ pukan kambing umumnya masih di atas 30. Pupuk kandang yang baik harus mempunyai rasio $\mathrm{C} / \mathrm{N}<20$, sehingga pukan kambing akan lebih baik penggunaannya bila dikomposkan terlebih dahulu. Kalaupun akan digunakan secara langsung, pukan ini akan memberikan manfaat yang lebih baik padamusim kedua pertanaman.Kadar air pukan kambing relatiflebih rendah dari pukan sapi dan sedikit lebihtinggi dari pukan ayam. Kadar hara pukan kambing mengandung kalium yang relative lebih tinggi dari pukan lainnya. Sementara kadar hara $\mathrm{N}$ dan $\mathrm{P}$ hampir sama dengan pukan lainnya. 
Ditinjau dari aspek klimatologis Indonesia sangat tepat untuk dikembangkan untuk bisnis sayuran.Laju pertumbuhan produksi sayuran di Indonesia berkisar andara 7,724, 20\%/ tahun. Beberapa jenis sayuran, seperti bawang merah, petsai/sawi, dan mentimun peningkatan produksinya merupakan dampak dari penerapan teknologi budidaya (Suwandi, 2009).

Salah satu faktor penting dalam budidaya yang menunjang keberhasilan hidup tanaman adalah masalah pemupukan. Masalah umum dalam pemupukan adalah rendahnya efisiensi serapan unsur hara oleh tanaman. Efisiensi pemupukan $\mathrm{N}$ dan $\mathrm{K}$ tergolong rendah, berkisar antara 30-40\% (Suwandi, 2009). Tanaman tidak cukup hanya mengandalkan unsur hara dari dalam tanah saja.Oleh karena itu tanaman perlu diberi unsur hara tambahan dari luar, yaitu berupa pupuk (Prihmantoro, 2001). Upaya peningkatan efisiensi penggunaan pupuk dapat ditempuh melalui prinsip tepat jenis, tepat dosis, tepat cara, tepat waktu aplikasi, dan brerimbang sesuai kebutuhan tanamaan (Syafruddin dkk, 2009).

Untuk dapat tumbuh dan produksi optimal, tanaman sayuran membutukan hara esensial selain radiasi surya, air, dan CO2.Unsur hara esensial adalah nutrisi yang berperan penting sebagai sumber unsur hara bagi tanaman.Ketersediaan masing-masing unsur tersebut di dalam tanah berbeda antar tanaman (Suwandi, 2009).

Peningkatan produksi sawi dapat dilakukan dengan pemupukan.Pumupukan melalui tanah dapat di lakukan dengan pupuk buatan dan pupuk alami.Maka perlu dilakukan penelitinan terhadap jenis pupuk kandang (pupuk kandang sapi dan pupuk kandang kambing) dan dosis pupuk Nitrogen terhadap pertumbuhan dan hasil tanaman sawi, (Brassica Juncea L).

\section{METODE PENELITIAN}

Percobaan ini dilaksanakan di laboratorium Fakultas Pertanian
Universitas Merdeka Surabaya.Ketinggian tempat kurang lebih $5 \mathrm{~m}$ di atas permukaan laut. Bahan penelitian yang digunakan yaitu : benih sawi, media tanam terdiri dari tanah kebun, pupuk kandang terdiri dari kandang sapi, kandang kambing, pupuk Nitrogen dan alat yang digunakan adalah Polybag ukuran 35 x $35 \mathrm{~cm}$, sprayer, alat ukur.

Percobaan ini disusun secara faktorial dalam Rancangan Acak Kelompok (RAK), terdiri dari dua faktor yaitu : Perlakuan macam pupuk kandang dengan 2 level dan perlakuan pupuk nitrogen dengan 4 level. Masing-masing kombinasi perlakuan diulang tiga kali dan setiap kombinasi perlakuan terdiri 2 (dua) tanaman sample. Faktor I :Macam pupuk kandang $\left(\mathrm{K}_{1}\right.$ : kandang sapi dan $\mathrm{K}_{2}$ : kandang kambing). Faktor II :Pupuk Nitrogen $\left\{\mathrm{N}_{1}: 50 \mathrm{gr} / \mathrm{m}^{2}(4.50 \mathrm{gr} / \tan ) ; \mathrm{N}_{2}\right.$ : $75 \mathrm{gr} / \mathrm{m}^{2}$ ( $\left.6,75 \mathrm{gr} / \mathrm{tan}\right) ; \mathrm{N}_{3}: 100 \mathrm{gr} / \mathrm{m}^{2}$ $(9,00 \mathrm{gr} / \mathrm{tan}) ; \mathrm{N}_{4}: 125 \mathrm{gr} / \mathrm{m}^{2}(11,25$ gr/tan) \}. Sehingga terdapat delapan (8) kombinasi perlakuan. Pengamatan yang dilakukan pada penelitian terdiri dari panjang tananmn; jumlah daun dan berat segar tanaman

Pengamatan yang dilakukan pada penelitian terdiri dari:panjang tanaman; jumlah daun; dan berat segar tanaman.

Pengamatan panjang tanaman dilakukan dengan cara mengukur panjang tanaman dimulai dari permukaan tanah sampai dengan daun terpanjang dengan cara menelangkupkan daun kearah atas, dan pengukuran dimulai pada saat tanaman berumur 1 minggu dengan interval 7 hari sekali sampai panen.

Pengamatan jumlah daun dilakukan dengan cara menghitung semua daun yang telah membuka sempurna, pengamatan dilakukan pada saat tanaman berumur 1 minggu setelah tanam dengan interval 7 hari sekali sampai panen.

Pengamatan berat segar tanaman dilakukan dengan cara menimbang semua bagian tanaman yaitu terdiri dari daun, 
batang dan akar. Penimbangan dilakukan pada akhir pengamatan (saat panen).

\section{HASIL DAN PEMBAHASAN Panjang Tanaman}

Hasil analisis ragam menunjukkan bahwa interaksi antara perlakuan macam pupuk kandang dan pupuk Nitrogenterhadap panjang tanaman pada semua umur pengamatan tidak menunjukan perbedaan yang nyata.Secara terpisah perlakuan macam pupuk kandangdan pupuk Nitrogenterhadap panjang tanaman berbeda sangat nyata pada umur pengamatan 14 HST.Pada umur 21 HST dan 28 HST perlakuan macam pupuk kandang terhadap panjang tanaman tidak berbeda nyata, sedangkan perlakuan pupuk Nitrogen menunjukkan perbedaan yang nyata pada semua umur pengamatan. Tabel 1. Rata-rata Panjang Tanaman Akibat UjiMacam Pupuk Kandang dan Pupuk Nitrogen Pada Berbagai Umur Pengamatan

\begin{tabular}{|c|c|c|c|}
\hline \multirow{2}{*}{ Perlakuan } & \multicolumn{3}{|c|}{ Panjang Tanaman (cm) } \\
\hline & 14 HST & 21HST & 28HST \\
\hline N1 & $16,42 \mathrm{a}$ & $21,08 \mathrm{a}$ & $34,58 \mathrm{a}$ \\
\hline N2 & $18,17 \mathrm{ab}$ & $22,33 \mathrm{a}$ & $38,17 \mathrm{~b}$ \\
\hline N3 & $19,83 \mathrm{bc}$ & $22,92 \mathrm{a}$ & $38,58 \mathrm{bc}$ \\
\hline $\mathrm{N} 4$ & $20,50 \mathrm{c}$ & $25,00 \mathrm{~b}$ & $42,08 \mathrm{c}$ \\
\hline BNT 5\% & 1,92 & 1,85 & 3,53 \\
\hline K1 & $17,54 \mathrm{a}$ & 22,67 & 37,04 \\
\hline $\mathrm{K} 2$ & $19,52 \mathrm{~b}$ & 23,00 & 39,67 \\
\hline BNT 5\% & 1,36 & tn & tn \\
\hline \multirow[t]{3}{*}{ Keterangan } & \multicolumn{3}{|c|}{$\begin{array}{l}\text { didampingi huruf yang } \\
\text { berbeda pada kolom yang }\end{array}$} \\
\hline & \multicolumn{3}{|c|}{ berbeda nyata pada uji } \\
\hline & $\begin{array}{l}\text { HST } \\
\text { Tanam }\end{array}$ & \multicolumn{2}{|c|}{ : Minggu Setelah } \\
\hline
\end{tabular}

tn : Tidak nyata

Rata-rata panjang tanaman pada perlakuan macam pupuk kandang dan pupuk Nitrogendapat dilihat pada Tabel 1. Tabel 1 menunjukkan bahwa perlakuan
Nitrogen sebanyak $125 \mathrm{gram} / \mathrm{m}^{2}$ (N4) menunjukkan panjang tanaman terpanjang pada semua umur pengamatan, masingmasing adalah 20,50 cm (umur 14 HST); $25,00 \mathrm{~cm}$ (umur $21 \mathrm{HST}$ ) dan 42,08 cm (umur 28 HST). Sedangkan panjang tanaman terendah diperoleh pada perlakuan Nitrogen sebanyak 50 gram $\mathrm{m}^{2}(\mathrm{~N} 1)$. Pada perlakuan macam pupuk kandang menunjukkan bahwa panjang tanaman terpanjang diperoleh pada perlakuan macam pupuk kambing (K2), masing-masing yaitu 19,52 cm (14 HST); $23 \mathrm{~cm}$ (21 HST) dan $39,67 \mathrm{~cm}$ (umur $28 \mathrm{HST}$ ). Dan panjang tanaman terendah diperoleh pada perlakuan macam pupuk kandang sapi (K1).

\section{Jumlah Daun}

Hasil analisis ragam menunjukkan bahwa terdapat interaksi yang nyata antara perlakuan macam pupuk kandang dan pupuk Nitrogenterhadap jumlah daun pada umur pengamatan 14 HST dan tidak menunjukan interaksi yang nyata pada umur 21 HST dan umur 28 HST. Secara terpisah perlakuan macam pupuk kandang dan pupuk Nitrogenterhadap jumlah daun berbeda nyata pada umur pengamatan 14 HST.Pada umur 21 HST dan 28 HST perlakuan macam pupuk kandang terhadap jumlah daun tidak berbeda nyata, sedangkan perlakuan pupuk Nitrogen menunjukkan perbedaan yang nyata pada semua umur pengamatan.Ratarata jumlah daun pada perlakuan macam pupuk kandang dan pupuk Nitrogenserta kombinasi perlakuannyadapat dilihat pada Tabel 2 dan Tabel 3.

Tabel 2. Rata-rata Jumlah Daun Akibat UjiMacam Pupuk Kandang dan Pupuk Nitrogen Pada Berbagai Umur Pengamatan

\begin{tabular}{|c|c|c|c|}
\hline \multirow{2}{*}{ Perlakuan } & \multicolumn{3}{|c|}{ Panjang Tanaman (cm) } \\
\cline { 2 - 4 } & 14 HST & 21HST & 28HST \\
\hline N1 & $4,42 \mathrm{a}$ & $5,92 \mathrm{a}$ & $7,42 \mathrm{a}$ \\
\hline N2 & $4,67 \mathrm{a}$ & $5,92 \mathrm{a}$ & $8,25 \mathrm{ab}$ \\
\hline N3 & $5,17 \mathrm{bc}$ & $6,67 \mathrm{~b}$ & $8,83 \mathrm{~b}$ \\
\hline N4 & $5,25 \mathrm{c}$ & $6,83 \mathrm{~b}$ & $9,75 \mathrm{c}$ \\
\hline
\end{tabular}




\begin{tabular}{|c|c|c|c|}
\hline BNT 5\% & 0,44 & 0,44 & 0,92 \\
\hline $\mathrm{K} 1$ & $4,67 \mathrm{a}$ & $6,13 \mathrm{a}$ & 8,54 \\
\hline $\mathrm{K} 2$ & $5,08 \mathrm{~b}$ & $6,54 \mathrm{~b}$ & 8,58 \\
\hline BNT 5\% & 0,31 & 0,40 & tn \\
\hline Keterangan & $:$ Angka-angka yang \\
& didampingi huruf yang \\
& berbeda pada kolom yang \\
& sama menunjukkan \\
& berbeda nyata pada uji \\
& BNT 5\% : Minggu Setelah \\
& HST : Tanam \\
tn & : Tidak nyata
\end{tabular}

Tabel 3. Rata-rata Jumlah Daun Akibat Uji Kombinasi Macam Pupuk Kandang dan Pupuk NitrogenPada Umur Pengamatan 14 HST

\begin{tabular}{|c|c|}
\hline Perlakuan & Jumlah Daun (Helai) \\
\hline K1 N1 & $3,67 \mathrm{a}$ \\
\hline $\mathrm{K} 1 \mathrm{~N} 2$ & $4,50 \mathrm{~b}$ \\
\hline $\mathrm{K} 1 \mathrm{~N} 3$ & $5,32 \mathrm{c}$ \\
\hline $\mathrm{K} 1 \mathrm{~N} 4$ & $5,17 \mathrm{c}$ \\
\hline $\mathrm{K} 2 \mathrm{~N} 1$ & $5,17 \mathrm{c}$ \\
\hline $\mathrm{K} 2 \mathrm{~N} 2$ & $4,83 \mathrm{bc}$ \\
\hline $\mathrm{K} 2 \mathrm{~N} 3$ & $5,00 \mathrm{bc}$ \\
\hline $\mathrm{K} 2 \mathrm{~N} 4$ & $5,33 \mathrm{c}$ \\
\hline BNT 5\% & \multicolumn{1}{|c|}{0,63} \\
\hline Keterangan & $\begin{array}{l}\text { :Angka-angka } \\
\text { didampingi huruf yang } \\
\text { berbeda pada kolom yang } \\
\text { sama menunjukkan } \\
\text { berbeda nyata pada uji } \\
\text { BNT 5\% }\end{array}$ \\
2
\end{tabular}

Tabel 2 menunjukkan bahwa perlakuan pupuk Nitrogen sebanyak 125 $\mathrm{gram} / \mathrm{m}^{2}$ (N4) menunjukkan jumlah daun terbanyak pada semua umur pengamatan, masing-masing adalah 5,25 helai (umur 14 HST); 6,83 helai (umur 21 HST) dan 8,83 helai (umur 28 HST). Sedangkan jumlah daun terendah diperoleh pada perlakuan pupuk Nitrogen sebanyak 50 gram $\mathrm{m}^{2}(\mathrm{~N} 1)$. Pada perlakuan macam pupuk kandang menunjukkan bahwa jumlah daun terbanyak diperoleh pada perlakuan macam pupuk kambing (K2), masing-masing yaitu 5,08 helai (14 HST); 6,54 helai (21 HST) dan
8,58 helai (umur 28 HST). Dan jumlah daun terendah diperoleh pada perlakuan macam pupuk kandang sapi (K1).Tabel 3 menujukkan bahwa kombinasi perlakuan macam pupuk kandang kambing dan pupuk Nitrogensebanyak $125 \mathrm{gram} / \mathrm{m}^{2}$ (K2N4), memberikan hasil jumlah daun terbanyak, yaitu sebesar 5,33 helai, yang tidak berbeda nyata dengan perlakuan K1N3 sebanyak 5,22 helai.

\section{Berat Basah Tanaman}

Hasil analisis ragam menunjukkan bahwa terdapat interaksi yang nyata antara perlakuan macam pupuk kandang dan pupuk Nitrogenterhadap berat basah tanaman pada akhir pengamatan.Secara terpisah perlakuan macam pupuk kandang terhadap berat basah tanaman berbeda nyata sedangkan perlakuan pupuk Nitrogenmenunjukkan perbedaan yang sangat nyata.Rata-rata jumlah daun pada perlakuan macam pupuk kandang dan pupuk Nitrogenserta kombinasi perlakuannyadapat dilihat pada Tabel 4 dan Tabel 5.

Tabel 4. Rata-rata Berat Basah Akibat UjiMacam Pupuk Kandang dan Pupuk NitrogenPada Akhir Pengamatan

\begin{tabular}{|c|c|}
\hline Perlakuan & Jumlah Daun (Helai) \\
\hline K1 N1 & $3,67 \mathrm{a}$ \\
\hline $\mathrm{K} 1 \mathrm{~N} 2$ & $4,50 \mathrm{~b}$ \\
\hline $\mathrm{K} 1 \mathrm{~N} 3$ & $5,32 \mathrm{c}$ \\
\hline $\mathrm{K} 1 \mathrm{~N} 4$ & $5,17 \mathrm{c}$ \\
\hline $\mathrm{K} 2 \mathrm{~N} 1$ & $5,17 \mathrm{c}$ \\
\hline $\mathrm{K} 2 \mathrm{~N} 2$ & $4,83 \mathrm{bc}$ \\
\hline $\mathrm{K} 2 \mathrm{~N} 3$ & $5,00 \mathrm{bc}$ \\
\hline $\mathrm{K} 2 \mathrm{~N} 4$ & $5,33 \mathrm{c}$ \\
\hline BNT 5\% & 0,63 \\
\hline Keterangan & $\begin{array}{c}\text { Angka-angka yang } \\
\text { didampingi huruf yang } \\
\text { berbeda pada kolom yang } \\
\text { sama menunjukkan } \\
\text { berbeda nyata pada uji } \\
\text { BNT 5\% }\end{array}$
\end{tabular}


Tabel 5 menunjukkan bahwa perlakuan pupuk Nitrogensebanyak 125 gram $/ \mathrm{m}^{2}$ (N4) menunjukkan berat basah terbesar yaitu 240,82 gram. Sedangkan berat basah terendah diperoleh pada perlakuan pupuk Nitrogensebanyak 50 gram $\mathrm{m}^{2}$ (N1). Pada perlakuan macam pupuk kandang menunjukkan bahwa berat basah tanaman terbanyak diperoleh pada perlakuan macam pupuk kambing (K2), yaitu 186,98 gram. Dan berat basah tanaman terendah diperoleh pada perlakuan maccam pupuk kandang sapi (K1). Tabel 5 menujukkan bahwa kombinasi perlakuan macam pupuk kandang kambing dan pupuk Nitrogensebanyak $125 \mathrm{gram} / \mathrm{m}^{2}$ (K2N4), memberikan hasil berat segar tanaman terbanyak, yaitu sebesar 259,94 gram.

\section{Pembahasan}

Hasil penelitian menunjukkan bahwa perlakuan pupuk kandang kambing (K2) memberikan hasil terbaik pada pertumbuhan dan hasil tanaman sawi, baik pertumbuhan panjang tanaman, jumlah daun ataupun berat basah.Hal ini disebabkan karena pemberian pupuk kandang mampu meningkatkan kesuburan tanah dan memperbaiki struktur tanah, dimana struktur tanah yang baik menyebabkan perakaran berkembang dengan baik, sehingga penyerapan unsurunsur hara dapat berlangsung secara maksimal. Sesuai dengan pendapat Nurhayati (2000), yang mengatakan bahwa kelancaran proses penyerapan unsur hara oleh tanaman terutama tergantung dari persediaan air tanah yang berhubungan erat dengan kapasitas menahan air oleh tanah. Dan didukung oleh Sutejo(2002), yang mengatakan bahwa pupuk organic mempunyai fungsi yang penting dibandingkan dengan pupuk anorganik yaitu dapat menggemburkan lapisan permukaan tanah (topsoil), meningkatkan populasi jasad renik, mempertinggi daya serap dan daya simpan air, yang secara keseluruhan dapat meningkatkan kesuburan tanah.

Kotoran kambing atau pupuk kandang kambing mempunyai kandungan hara yang lebih baik dibanding dengan pupuk kandang sapi, dimana kandungan hara dapat mempengaruhi pertumbuhan dan perkembangan tanaman. Hal ini sesuai dengan pendapat Handoko (2000, dalam Dora, dkk. 2013), pemberian pupuk kandang memberikan pengaruhterhadap pertumbuhan dan hasiltanaman sawi.Sedangkan menurut Dora, dkk.(2013), bahwa pemberian pupuk organik kotoran kambingmemberikan pengaruh terhadap peubahtinggitanaman, jumlahdaun, luas daun dan beratberangkasan basah.

Perlakuan pemupukan dengan pupuk Nitrogen $\mathbf{N}_{4}$ memberikan hasil pertumbuhan dan perkembangan tanaman sawi terbaik dibanding dengan perlakuan yang lain. Hal ini disebabkan karena pupuk Nitrogensangat besar kegunaannya bagi tanaman untuk pertumbuhan dan perkembangan. Sesuai dengan pendapat Sofiati N. (2012), yang mengatakan bahwa pupuk Nitrogensangat besar kegunaannya bagi tanaman untuk pertumbuhan dan perkembangan, antara lain: Membuat daun tanaman lebih hijau segar dan banyak mengandung butir hijau daun (chlorophyl) yang mempunyai peranan sangat panting dalam proses fotosintesis; Mempercepat pertumbuhan tanaman (tinggi, jumlah anakan, cabang dan lain-lain); Menambah kandungan protein tanaman; Dapat dipakai untuk semua jenis tanaman baik tanaman pangan, holtikultura, tanaman perkebunan, usaha peternakan dan usaha perikanan.

Nitrogen merupakan salah satu bahan pembentuk protein yang dibutuhkan bagi pembangunan protoplasma.Oleh karena itu nitrogen merupakan komponen esensial bagi semua bahan hidup (Soemarno, 1980 dan Effendi, 1990). Diantara tiga unsur pupuk anorganik yang umum diberikan, Nitrogen mempunyai 
efek yang paling cepat dan paling tampak pada pertumbuhan tanaman (Soepardi, 1979). Fungsi Nitrogen yang selengkapnya bagi tanaman adalah sebagai berikut: untuk meningkatkan pertumbuhan tanaman, dapat menyehatkan pertumbuhan daun, meningkatkan kadar protein dalam tubuh tanaman, meningkatkan kualitas tanaman penghasil daun, meningkatkan perkembangan mikroorganisme dalam tanah (Kartasapoetra dan Sutedja, 2000).

Perlakuan kombinasi $\quad \mathrm{K}_{2} \mathrm{~N}_{4}$ memberikan hasil tertinggi pada jumlah daun dan berat basah tanaman, hal ini dikarenakan dengan adanya pupuk kandang menyebabkan kondisi tanah yang sangat mendukung bagi perkembangan perakaran maupun proses penyerapanya, selain juga kebutuhan tanaman akan unsur hara tercukupi selama pertumbuhannya, baik yang berasal dari pupuk organik maupun anorganik (Nitrogen). Dengan penambahan bahan organik maka sifat pupuk Nitrogenyang mudah hilang akan diperkecil karena pupuk organik mampu mengikat unsur hara dan menyediakan unsur hara sesuai kebutuhannya, sehingga dengan adanya pupuk organik efektifitas dan efisiensi pemupukan menjadi lebih tinggi.

Sesuai dengan pendapat Yunus (1991), bahwa bahan organik yang dikandung oleh pupuk organik mampu bersatu dan membalut partikel-partikel tanah menjadi butiran-butiran tanah yang lebih besar.Butiran-butiran tanah tersebut mampu menyimpan unsur hara anorganik dan menyediakan pada saat tanaman memerlukannya.Selain itu pupuk organik yang diberikan dapat membuat keseimbangan hara di dalam tanah dan meningkatkan mutu fisik tanah dengan membuat tekstur tanah, porositas dan struktur tanah menjadi lebih baik.Sehingga penyerapan unsur hara optimal.Ditambahkan oleh Hairiah et al., (2000), bahwa bahan organik dapat meningkatkan kapasitas tukar kation tanah dan mengurangi kehilangan unsur hara yang ditambahkan melalui pemupukan sehingga dapat meningkatkan efisiensi pemupukan.

Penambahan bahan organik sangat membantu dalam memperbaiki tanah yang terdegradasi, karena pemakaian pupuk organik dapat mengikat unsur hara yang mudah hilang serta membantu dalam penyediaan unsur hara tanah sehingga efisiensi pemupukan menjadi lebih tinggi. Hal ini didukung oleh pendapat Rukmana (1995), bahwa untuk mencapai hasil yang maksimal, pemakaian pupuk organik hendaknya diimbangi dengan pupuk buatan supaya keduanya saling melengkapi.Salah satunya adalah pupuk Nitrogen.Hal ini sesuai dengan pendapat Hegde dan Dwivedi (1993), bahwa pemberian bahan organik ke dalam tanah dapat membantu meningkatkan efisiensi penggunaan pupuk kimia melalui perbaikan sifat fisik, kimia dan biologi tanah serta mempunyai pengaruh nyata pada hasil tanaman.Pemberian pupuk organik saja belum menjamin kecukupan unsur hara bagi tanaman tetapi dapat memberikan kondisi yang lebih baik bagi pertumbuhan akar.

\section{KESIMPULAN}

Hasil penelitian menunjukkan bahwa uji pertumbuhan dan hasil tanaman sawi dengan pemberian macam pupuk organik dan pupuk nitrogen dapat disimpulkan sebagai berikut :

1. Terdapat interaksi yang nyata pada perlakuan kombinasi macam pupuk kandang dan pupuk Nitrogen terhadap variabel jumlah daun umur 14 HST dan berat basah tanaman. Hasil terbaik ditunjukkan oleh perlakuan kombinasi $\mathrm{K}_{2} \mathrm{~N}_{4}$

2. Perlakuan macam pupuk kandang berpengaruh sangat nyata terhadap pertumbuhan panjang tanaman umur 14 HST dan berat basah tanaman, sedang pertumbuhan jumlah daun berbeda nyata umur 14 HST. Hasil terbaik 
ditunjukkan oleh perlakuan pupuk kandang kambing $\left(\mathrm{K}_{2}\right)$

3. Perlakuan pupuk Nitrogen berpengaruh sangat nyata terhadap semua variabel pengamatan. Hasil terbaik ditunjukkan oleh perlakuan $\mathrm{N}_{4}$.

\section{DAFTAR PUSTAKA}

Dora, dkk. (2013.

PengaruhPemberianPupukOrgani $\mathrm{k}$

TerhadapPertumbuhandanHasilTa namanSawiCaisim (Brassica

JunceaL.). Jurnal.Agrobisnis.Vol

1. No 1. Maret 2009

Handoko.2000. "Pengaruh

PemberianPupuk Kandang".

Palembang: Fakultas Pertanian

Haryanto, E. Suhartini, T.Rahayu,E. 2003.

SawiDan Selada. Jakarta:

Penebar Swadaya.

Hairiah, K., H., Widianto ., S.R. Utami., D. Suprayogo ., Sunaryo., S.M. Sitompul., B. Lusiana., R. Mulia ., M.Van Noordwijk dan G. Cadisch, 2000. Pengelolaan Tanah Masam Secara Biologi. ICRAF. Bogor.

Hegde dan Dwivedi (1993). Integrated Nutrient Supply and Management as a Strategy To Meet Nutrient Demand In : Fert News. 38: 49-59.

Kartasapoetra dan Sutedja.2000. Teknologi Konservasi Tanah danAir.RinekaCipta, Jakarta.Hal 14.

Nurhayati. 2000. Dasar-Dasar Ilmu Tanah.

BandarLampung:UniversitasLampu ng.

Rukmana, R. 1995. Usaha Tani Jagung. Kanisius.Yogyakarta.
Rukmana. 2003.Pengaruh Konsentrasi dan waktu penyemprotanPupuk Oganik Cair POC Super ACI terhadapPertumbuhandan Hasil Tanaman. Jagung Manis

Sofiati N. 2012. Pengaruh pupuk urea terhadap pertumbuhan dan hasil tanaman selada (Lactuca sativa). Program studi Agroteknologi Fakultas Pertanian Universitas Muria Kudus 2012.http://cophierastafaras.blogsp ot.com/2012/07/pengaruh-pupukurea-terhadap. html

Sutejo(2002), Sutejo, BPS,2002. pupuk dan cara pemupukan, Reneka Cipta Hal 25-26.

Sari, I. P., Hidayati, S., Ali, M., \& Purwanti, S. (2020). Application of Urban Waste Organic Fertilizer on the Growth of Mustard Plants (Brassica Juncea L.). Agricultural Science, 4(1), 74-84.

Yunus, M. 1991. Pengelolaan Limbah Peternakan. Jurusan Produksi Ternak LUW-Universitas Brawijaya. Animal Husbandry Project.p.117.

Yitnosumarto. S. 1991. Percobaan, perancangan, Analisis dan intrpretasinya Dep. $\mathrm{P}$ dan $\mathrm{K}$. Program MIPA Unibraw. 